\title{
Going Against the Grain in Literary Studies. An Analysis of Boosters, Hedges and other Rhetorical Strategies in The Pilgrimage of Dorothy Richardson by Joanne Winning
}

\author{
María Francisca Llantada Díaz \\ University of Vigo \\ fanny.llantada@uvigo.es
}

\begin{abstract}
In The Pilgrimage of Dorothy Richardson (2000), Joanne Winning negotiates her claim to credibility in the world of Richardson's studies when introducing a theory that goes against the grain. The study of boosters, hedges and other rhetorical strategies in its introduction and afterword will be of key importance to show how Winning conciliates her self-assurance about her proposal with her deference to other researchers. Researchers are able to convince their colleagues if they have full command of rhetorical strategies to present their findings in an acceptable way. Thus, this article will analyse how boosters, hedges and the coexistence of selfmention with impersonalization strategies help Winning create an adequate scholarly identity for herself that guarantees her inclusion in the literary critical scene.
\end{abstract}

\section{Introduction. Boosters and hedges in academic language}

The Pilgrimage of Dorothy Richardson (2000) has been selected as the object of study of this article because of its representativeness as an example of an unambiguous challenge to the critical panorama of Dorothy Richardson's studies. The aim of this paper will be to study the function of boosters, hedges and other rhetorical strategies in this book by Joanne Winning. This will show the ways in which the author negotiates knowledge and claims credibility in the academic panorama of Richardson's studies. The introduction and afterword of Winning's book are particularly interesting from the point of view of the study of boosters, hedges and 
various rhetorical strategies used to present innovative research findings to the academic community. This is so because it is in these sections where the author states her initial claims in a persuasive way and concludes defending her own position in the literary critical community.

Academic language is understood in this article as scientific language addressed to the scientific community. This type of community can be identified as a typical discourse community, understood as a group engaged in text reception or production that have texts and practices in common. Discourse community can refer to the people the text is aimed at, the people who read a text or the people who participate in a set of discourse practices by reading and writing. (Barton, 1994: 57).

As Ken Hyland (1998c: 439) has said, "for writers to publish and influence their fields, they must exploit their understanding of these academic] genres". Hyland considers boosting and hedging the most important tools researchers use to negotiate knowledge, thus modulating their discourses between the expression of certainty and doubt:

The expression of doubt and certainty is central to the rhetorical and interactive character of academic writing. Its importance lies in the fact that academics gain acceptance for their research claims by balancing conviction with caution, either investing statements with the confidence of reliable knowledge, or with tentativeness to reflect uncertainty or appropriate social interactions. (1998b: 349)

Solidarity is a key issue when presenting new theories, as knowledge and truth have to be conciliatory and consensually established rather than imposed. To claim membership in a disciplinary group is vital for researchers who want their theories to be admitted and approved by the academic community. Moreover, statements about research should be made with care and prudence and require circumspection and discretion. As Elija Ventola (1995: 126) has said: "doing research is not just a matter of writing up the results of the experiments, analyses, etc. - what one has to do is to convince your colleagues, to sell your research".

As Hyland (1998b: 350) notes, hedges and boosters have been considered effective communicative strategies that increase or reduce the force of statements and also convey an attitude to the audience. The publication of new findings in academic research implies that these new theories need to be accepted by the academic community, so that certain strategies are advisable to be used in order to favour the acceptation needed by the researcher. According to Hyland (1998b:350,351), boosting is sometimes used to stress "shared information, group membership and direct engagement with readers" and hedging to convey "deference, humility and respect for colleagues' views". These two functions of boosters and hedges will be taken into account in the analysis of Winning's presentation of her controversial theory in her book The Pilgrimage of Dorothy Richardson.

Besides the well-known use of hedges as part of disciplinary conventions affecting style, Myers (1989, quoted in Hyland, 1998b: 353) suggested that researchers use hedges "to minimize the potential threat new claims make on other researchers by soliciting acceptance and challenging their own work". Similarly, for Hübler $(1983: 157,22)$, hedges are face ${ }^{1}$ saving strategies that "lessen any possible virulent aggressive effect of the content on the hearer". The use of hedges is thus important in Winning's rhetorical practices because, as a 
researcher, she needs to achieve a balance between self-assurance and the deference and respect due to other colleagues. Moreover, with the use of hedges, new theories have more possibilities of being well-received and accepted by the academic community.

It is important to point out that in this essay we are dealing with literary criticism, one of the soft sciences clearly related with the humanities, and separated from the hard sciences having different conventions which vary according to the area (mathematics, medicine, biology, etc...). In the case of the hard sciences, using hedges avoids counterargumentations, experiments have to be replicated, if they fail, the claims made are not accepted as valid.

According to Hyland (1989b: 361), "soft-knowledge areas ...] are typically more interpretative and less abstract", so that "while a paper must carry conviction, it must also appeal more to the reader's willingness to follow the writer's reasoning". This means that the use of hedges is a key element in a so-called "soft-knowledge area" like literary criticism and a positive interaction with readers is of key relevance in order to convince and persuade readers. Boosters are also relevant in a soft-knowledge area because of their interpersonal role in the creation of a sense of solidarity and their appeal to the reader as an intelligent co-player in a close-knit group (Hyland, 1989:369).

The coexistence of self-mention and impersonalization strategies will also be studied by analysing its occurrences in Winning's text. As Hyland (2001: 223) has said, self-mention "plays a crucial role in mediating the relationship between writers' arguments and their discourse communities, allowing writers to create an identity as both disciplinary servant and persuasive originator". The presence of the first-person pronouns $I$ and we in a scientific text implies that researchers are showing their commitment. Bakhtin (1986:293) had pointed out that not using $I$ at all gives the impression that the writer is withdrawing from all responsibility for the academic essay. Similarly, Ivanic and Simpson (1992: 144) reject the idea that academic writing is objective and impersonal and point out that the $I$ makes you write your ideas, thoughts and convictions.

Despite the importance of the presence of the pronoun $I$ in academic language, according to Hyland (1989b: 364), minimizing writer presence by means of impersonalization strategies is also a common practice in academic publications and can also be found in Winning's text, as we will see in the following analysis. Impersonalization is achieved by means of the use of passives, nominalization and objective theme selections (Gosden, 1993; Halliday, 1988; Swales, 1990; quoted in Hyland, 1989b: 364) and it guarantees a positive interaction with readers, enabling the writer to "effectively interact with colleagues and secure agreement for one's arguments" (Hyland, 1989b: 372). However, this practice of impersonalization is more typical of the so-called hard sciences, and in the soft sciences it usually coexists with instances of self-mention, as we will prove later in our study of Winning's text.

Thus, scientific discourse proves to be a rhetorical artifact and "contributing to a scientific debate involves the writer entering into an interactional contact with specific rights and obligations, among which are limits on self-assurance and norms concerning the deference due to the views of other researchers" (Hyland, 1998a: 69). The aim of this paper is to see how this materializes in Winning's text. 


\section{Boosting and hedging in lesbian modernism}

This section includes an analysis of the introduction and afterword of The Pilgrimage of Dorothy Richardson. It has been divided into several subsections dealing with different issues related to boosters and hedges and the author's invisibility or invisibility.

\subsection{Inclusive we}

In The Pilgrimage of Dorothy Richardson, the author starts her introduction using inclusive we in order to place herself in the literary community which studies modernism in general. As Huddleston (2002: 1465) has pointed out, the term inclusive refers to the fact that the pronoun we includes the addressee. However, "the priority accorded to the speaker over the addressee ...] is reflected in the fact that a set containing both speaker and addressee is referred to by $1^{\text {st }}$ person we, not $2^{\text {nd }}$ person you" (p. 1466; emphasis in the original). It is also important to point out that the use of we can also be understood as "authorial we". As Huddleston (2000: 1467; emphasis in the original) notes: "written works authored by a single person often use we as a means of involving the reader and/or avoiding the $1^{\text {st }}$ person singular pronoun $I$ and the differences between inclusive we and authorial we are sometimes difficult to establish. For Hyland (2000: 127), inclusive we is used "to invite readers into the discussion by drawing on shared general knowledge" and "is used heavily to bind writer and reader together as members of a disciplinary in-group" (Hyland, 2004: 100).

In Winning's case, the form we is subtly introduced to refer to a community of literary academics and readers of Virginia Woolf's Mrs Dalloway: "It is a moment, we are told ...]" (2000: 3; emphasis added). Then, the cohesiveness of this academic group with a similar background is emphasized by the use of the word readers: "a]s readers of Woolf's novel, how are we to interpret the symbolism of this exquisite kiss?" (p. 3; emphasis added). The answer to this question seems to point to the divergences which will soon establish two clearly antagonist branches in this initially univocal group referred by the pronoun we: that of traditional criticism of Pilgrimage and the stream of lesbian interpretations of Pilgrimage defended by Winning. By the posing of this question and of several further questions, Winning (p. 4; emphasis added) expresses her disconformity with previous literary theories and suggests her certainty about the existence of a more satisfying analysis: "These questions multiply if we take them beyond the text and apply them to the life of Woolf herself in 1925: a prolific modernist writer at the height of her powers, married to Leonard Woolf, in love with Vita Sackville-West". After the previous questions, meant to point to the unsustainability of previous criticism, Winning's hypothesis is introduced with the adequate caution due when presenting a new opinion which contradicts all that has been said before: "Lesbian desire, indeed, seems to weave its way through the modernist period with great tenacity. If we were to track this thread through the canon of female modernism, we would formulate an impressive list" (p. 4; emphasis added). The adjective impressive is an explicit expression of authorial presence in the text, so this sentence could not be taken to be impersonal. The presence of two boosters, indeed and with great tenacity, and a hedge, the verb seems, establishes a point of equilibrium between the assertivity the author wants to give to her 
hypothesis and the degree of uncertainty which should be expressed as a means to express politeness and deference to other members of the academic literary community. The initial hedging indicated by the use of the conditional type III "If we were to ...] we would" is also counteracted by the presence of the booster impressive. Thus, the weight is on the author's certainty rather than on her lack of assertivity, but still, the use of hedging indicates caution and tentativeness in the formulation of her hypothesis.

\subsection{Techniques of invisibility}

After the use of the hedge (might): “[w] might expand the generic net and include poetry" (p. 4; emphasis added), the presence of boosters is highly increased, as the certainty of the author grows and she accumulates more proofs:

All these works, in various textual ways, articulate some kind of narrative of lesbian desire and identity. None of them may be clearly identifiable, by late twentieth-century standards, as straightforwardly lesbian texts (whatever that term might mean); yet in each, lesbian identity enunciates its presence in insistent textual terms. The list above is by no means exhaustive and can be extended by the inclusion of other works by these authors and others. (p. 4; emphasis added except in the word "lesbian")

In this passage the presence of the hedge some kind of - indicating indeterminacy or uncertainty - and the expression of doubt indicated by "[n]one of them may be clearly identifiable [...] as straightforwardly [...]" is counteracted by the certainty expressed by the boosters yet, which contradicts all that has been said before, and insistent, which has a clear parallelism with the previously used expression with great tenacity. The qualities of insistence and tenacity are thus attributed to the texts themselves, not to the author who formulates the hypothesis:

Lesbian desire [...] seems to weave [...] with great tenacity

lesbian identity enunciates its presence in insistent textual terms

In both constructions, lesbian desire and lesbian identity are presented as the subjects, thus contributing to the invisibility of the author, hidden behind these apparently self-evident and objective truths. The author's self-assurance about her project and her promise of further reasons to confirm her hypothesis are expressed by the boosters included in the last part of the paragraph quoted above: "[ $\mathrm{t}]$ he list above is by no means exhaustive and can be extended" ( $\mathrm{p}$. 4; emphasis added). The author is here reassuring about the solidity of her hypothesis and her self-confidence is present in the use of the boosters by no means and the verb can.

After this introduction of questions that express her disconformity with criticism on Dorothy Richardson, Winning quotes the opinions of several critics and, again, takes an unanswered question as her point of departure:

Yet, as full as this investigation into the refractions of gender on modernism continues to be, we have not answered Minow's invocation to learn to call this work "lesbian modernism." Since 1987 
[...] it has become clear that there are fundamentally complex yet crucial relations between lesbian sexuality and textuality in the modernist period. (p. 5; emphasis added and quotation marks in the original)

The author's insatisfaction with the present state of Dorothy Richardson's criticism is thus clearly enunciated. Inclusive we could be taken to indicate that the author's insatisfaction with present theories could be shared by a part of the academic community. The boosters yet and it has become clear emphasize the author's growing certainty about the theories she is going to expand in her book. Moreover, it has become clear is an anticipatory expression unveiling the author's presence again.

The hedging implied by the use of conditional type III to express uncertainty is again counteracted by the presence of the booster certainly, which indicates the author's declared certainty and invalidates the degree of doubt expressed by the use of the conditional: "If we were to conceive of their work as 'lesbian modernism', we would certainly have to take in a broad range of issues" (p. 5; emphasis added). The author's growing assertiveness is further developed in her use of the booster proves to express certainty: "[a]s the existence of this network proves" (p. 5; emphasis added). The author uses the passive to make a very general claim: "questions of cultural production are now understood to be central to the terms of modernism" (p. 5; emphasis added). As Biber (1999: 935) notes, "the passive involves a restructuring of the clause" and it "serves the discourse functions of cohesion and contextual fit through [...] omission of information". This use of the passive voice without an agent is often an impersonalising technique that allows writers to give an impression of objectivity or to avoid commitment (Hyland, 1998a: 77). However, in this particular case, the passive indicates that the author is making a very general claim, which is likely to be shared by the whole academic community.

\subsection{Boosters and hedges}

The change from conditional type III to conditional type I indicates a definitive change from previous caution to more open conviction: "If we think in terms of cultural production, then we must broaden the terms of lesbian influence" (Winning, 2000: 5; emphasis added). The verb must is a booster that strengthens the author's degree of certainty about her theory. The necessity to broaden the terms of lesbian influence is thus settled as the author's objective in her book. The author's admission of the ambiguity of the term lesbian is not seen as a drawback, but as an advantage:

Reading across these lives and texts, the term lesbian is constantly destabilized, yet reaffirmed; it becomes a shadowy figure whose fragmentary form disrupts and reforms modernism's master narrative of heterosexuality, and whose meanings [...] multiply [...]. (p. 7; emphasis added except in the word "lesbian")

The hedges in this passage referring to the term lesbian (destabilized, shadowy and fragmentary) are neutralized by the boosters yet reaffirmed and the verbs disrupts and reforms. The hedges indicate qualities which at first sight could be seen as hindrances, but that 
are identified by the author as the origin of the term's strength, giving it the power to disrupt and reform, and multiplying its meanings. From this position of power, the author makes an assertive statement of her project:

Thus, the theorization of lesbian modernism must strive for the development of a lesbian poetics of modernist form, which may indeed map certain formulations of the modernist aesthetic, but which is also crucially distinctive in its attempt to record lesbian sexuality. (p. 7; emphasis added)

The use of the boosters must, indeed and crucially distinctive is an indication that the author's assertiveness is increasing, and she explains the reasons for her growing certainty in the following terms: "It may well be that we are now equipped with suitable theoretical tools, at the end of the twentieth century, to excavate the sexualities of lesbian modernism at the beginning of the century" (p. 7; emphasis added). Despite the use of the hedge may well to indicate caution in the expression of a proposition, the author is actually openly showing her confidence in the validity of the explorations made in her book, as the use of the booster suitable indicates.

\subsection{The use of the pronoun $I$}

The inclusive we that appears in the last fragment of the previous subsection and that could be interpreted as a sign of the author's sympathetic relationship with other critics will soon be replaced with the pronoun $I$, as the author could be said now to have reached a degree of certainty that enables her to use the first person singular. Winning does this after quoting other critics in order to support her reasoning. From this standpoint, the author feels confident enough to express her opinions in the first person:

Such a model of sexuality, I believe, is necessary to counteract the reductive reading of female modernist lives and texts [...] In extending my notion of lesbian modernism, I do not believe that such a frame should operate [...]. It is simply not possible either to [...] I am seeking to pluralize [...] In this sense I do not believe that its formulation will be particularly easy or consistently cohesive. Moreover, I do not believe that it is only lesbian scholars, or lesbian readers, who can or should undertake such a project. What $I$ do believe most firmly is that some reckoning must be made of the insistent trace of lesbian identity and creativity which we find [...]. To go some small way toward this coming to terms is the aim of this book. With all these provisos, complexities, and possibilities in mind, I turn to the main body of this investigation [...]. (pp. 8-9; emphasis added)

This is a key passage of the book where the author explains her opinions about what should be done in the field of studies of English modernism. The firmness of her views is balanced by means of the repeated use of the hedge I believe, which mitigates her claims. She starts with I believe, then she uses I do not believe three times and ends with a cleft construction which emphasizes the crescendo in her certainty with the help of the booster most firmly: "What I do believe most firmly". Boosters such as must and insistent contribute to stress certainty. As Hyland (2000: 123) notes, "the impression of certainty, assurance and conviction in the views expressed is] strenghtened with the use of personal pronouns". Thus, the hedge believe is 
counterbalanced with the personal pronoun $I$ to express the author's assertiveness about her theories in a moderate but convinced way.

However, we should note the presence of some hedges to tone down the strength of the previous boosters. The second sentence including "I do not believe", for instance, is hedged by the expressions particularly easy and consistently cohesive: "I do not believe that its formulation will be particularly easy or consistently cohesive". The reference to "provisos, complexities, and possibilities" also hedges the author's commitment to the aims of her book. With the hedge some small way the author acknowledges that her project is a contribution to a larger plan described in a passive construction with an inclusive we which refers to the academic community in which the author inscribes her work: "some reckoning must be made of the insistent trace of lesbian identity and creativity which we find woven through the modernist period" (p. 9; emphasis added).

After the preliminary statement of her general aims, the author continues her introduction concentrating on her object of study: Dorothy Richardson. First she exposes the incompleteness and unsatisfactoriness of Richardson's studies in a firm and decided way:

Richardson and her unwieldy work have for years been neglected, missing from the literary history of modernism [...] her work has often been either misread or not read at all. There is no doubt that it presents a challenge to students and scholars alike, but until recently, I think, nobody has properly understood just how large that challenge is. [...] My argument in this book [...] is that one area of Pilgrimage in particular has been overlooked-its lesbian content. I will offer a reading of Richardson's Pilgrimage which speculates on the thread of lesbian desire [...] Such a reading is against the grain of Richardson's studies. (p. 9; emphasis added)

Winning describes Richardson and her work as "neglected, missing [...] misread [...] or not read at all", thus she presents herself as a qualified and authorized scholar who will attempt an alternative reading which, she knows, will not please all the academic community. In fact, she describes her reading as "against the grain of Richardson's studies" (p. 9), thus highlighting the reason why Winning's book has been chosen as the object of study of this article.

Winning's summary of the contents of her book starts with an objective tone which is characterized by the initial absence of the first person singular:

Pilgrimage offers itself as a particularly useful test case for trying out the term "lesbian modernism". [...] Thus, by reading Pilgrimage in its contexts, this books sic] plots the parameters of the relation between early twentieth-century configurations of sexuality and the textualities of this important modernist writer. (p. 10; emphasis added)

In this passage, Pilgrimage and The Pilgrimage of Dorothy Richardson are the subjects, so that all references to Winning as the author are deleted. Pilgrimage is the subject of the first clause. Winning attributes an active role to Richardson's novel, which is said to "offer itself" as a "useful test case", willingly submitting itself to Winning's analysis. Winning's book, on the other hand, is the subject of another clause: "this books sic] plots the parameters". In this way, the invisibility of the author is guaranteed. However, her implication becomes apparent 
if these sentences are rephrased with a first-person subject:

I have chosen Pilgrimage as a particularly useful test case [...]

I plot the parameters of the relation [...]

The invisibility of the author is also achieved in other examples where the first person is absent and statements are presented in an objective way. However, expressions such as "to locate the unlocatable" betray the presence of the author's voice:

However, the examination of the twin narratives of Richardson's life and Pilgrimage does expose a fragmented but identifiable theme of lesbian desire. In some senses, the attempt to read such a theme is an attempt to locate the unlocatable. (pp. 10-11)

The absence of the first person pronoun gives objectivity to the previous statements, which are not presented as opinions but as accepted facts. However, the pronoun $I$ appears in this summary of the book Winning makes in the introduction on several occasions, probably due to the conventions of the genre and usually referring to the work carried out in the different chapters: "In chapters 2 and 3, $I$ explore the ways" (p. 11; emphasis added); "In chapter 4, $I$ explore Richardson's textual experimentation" (p. 12; emphasis added); "In chapter 5, I explore the textual events" (p.12; emphasis added).

At the end of the introduction Winning's book is again presented as the subject of two clauses:

The present book does not seek to detract from the modernist status of Pilgrimage or to do disservice to Richardson's own intentions. It does, however, argue that in the test case of Pilgrimage [...] the literary, linguistic, and aesthetic project [...] coexists with modernist intentions. (pp. 10-11; emphasis added)

Again, the author uses her book as the subject in a pair of clauses to express her opinions, in a conventional accepted manner. This is also the way in which Winning chooses to open her afterword: "Mirroring Richardson's actions in the writing of Pilgrimage, this book seeks to find its end in its beginnings, returning to the questions outlined in its introduction on the terms of lesbian modernism" (p. 172; emphasis added). Again, some active decisions are attributed to the book itself, which is presented as having the capacity to seek to find its end and to return to the introduction. In fact, it is the author who wishes to conceal herself behind the book, which can be considered an objective entity. However, there is another sentence in the afterword in which the first person singular is used to refer to the fact that the afterword mirrors the introduction: "I thus return to the weighting-in-balance I conducted in the introduction" (p. 173). This occurrence of the first-person pronoun $I$ is toned down by the author's repeated use of inclusive we and her acknowledgement that her argumentation is "hedged": 2

The lesbian thread of modernism is complicated, hedged about by qualifiers and provisos; yet as we learn more about the hidden literary history of modernism we are constantly brought back to 
making some account of its forms and its presence. Where do we go from here? (p. 173; emphasis added)

Inclusive we also appears in the concluding paragraph of the afterword, so that the author's findings can be recognized and assimilated by the academic community as part of the knowledge which is produced in its circle. The author is appealing to her colleagues' sense of comradeship to end the book with a positive note. Thus, there is a movement from an initial weight on the use of $I$ in the introduction to an increase in the use of inclusive $w e$ in the afterword.

By putting different aesthetic forms together, we broaden our sense of the cultural moment; placing lesbian modernist writing in the context of its aesthetic counterparts allows us to begin to see the ways in which these cultural formations articulate the lesbian subject, [...] It may well be that as we leave this century, her forms are finally becoming visible to us (p. 175; emphasis added).

The effect achieved is that of shared knowledge in a calm, non-competitive way, necessary when a controversial theory is presented. The new theory is thus ready to be incorporated into the panorama of Richardson's studies as an enlargement, a new view that has something to add to previous criticism.

\section{Conclusions}

The study of hedging and boosting in the introduction and afterword of Winning's The Pilgrimage of Dorothy Richardson has proved to be very fruitful, as this is a book with a highly controversial claim where rhetorical strategies have to be carefully nuanced to achieve a positive interaction with readers. In order to make herself heard in the academic community, the author has to present her theories with prudence and care, so that hedges and boosters are a principal part of her rhetorical discourse to strengthen her claims and to express herself in an accepted and established way. On the one hand, we have seen that the author uses hedges as a means of self-protection and to lessen impositions on colleagues because of deference or courtesy. On the other hand, boosters are used to indicate the author's certainty about her theories and her inclusion in an academic community.

The analysis of the coexistence of some impersonalization strategies with self-mention has also proved to be rewarding. On some occasions the author has aimed at becoming invisible and giving a sense of objectivity by means of impersonal subjects and the passive, as impersonality has always been a guarantee of credibility. However, self-mention is equally important in Winning's book, as is the case in the soft-sciences, and has a high degree of appearance. We have studied how inclusive we was used by the author to persuade her readers by appealing to the sense of inclusiveness of the academic community. In fact, this is the way the book opens and closes. We have also seen that the generous use of the first person pronoun I when the author is stating her theories in the introduction - with fourteen occurrences - gives way to a scarce use of the pronoun $I$ in the afterword - with only two occurrences -, which could be said to indicate the author's prudence when stating her conclusions. Instead, 
inclusive we is used eight times in the afterword in what could be considered an appeal to the sympathy of the academic community the author is addressing.

Winning can be thus considered an author with full command of rhetorical and stylistic devices, which allows her to present her theories in a favourable way. Her initially controversial claims are carefully integrated in the current of Richardson's studies by means of a cautious discourse with a dexterous use of boosters and hedges and a successful combination of self-mention and impersonalization strategies. In this way, she carefully creates an adequate scholarly identity for herself that enables her to present her theories in an acceptable way, contributing to the construction of the disciplinary field of lesbian modernism.

\section{Notes}

1. Goffman's definition of "face" can help us to understand Hübler's notion of hedge: "The term face may be defined as the positive social value a person effectively claims for himself by the line others assume he has taken during a particular contact. Face is an image of self delineated in terms of approved social attributes" (Hübler, 1983: 5; emphasis in the original). For an interesting analysis on the implications of euphemism in relation to the notion of face within the framework of linguistic politeness, see Crespo Fernández's article "Euphemistic strategies in politeness and face concerns" (2005).

2. A great variety of hedges are used in the afterword: may, with three occurrences (pp. 172, 173); seems, with two occurrences (pp. 173, 174); might, with two occurrences (pp. 172, 173); it suggests, with one occurrence (p. 173); perhaps, with three occurrences (pp. 173, 174); and may well, with two occurrences (pp. 172, 175).

\section{References}

Bakhtin, M. (1986): "The problem of speech genres and the problem of the text in linguistics, philology and the human sciences: an experiment in philosophical analysis". In C. Emerson and M. Holquist, eds., Bakhtin: speech genres and other late essays. Austin: University of Texas Press, 250-317.

Barton, D. (1994): Literacy: An Introduction to the Ecology of Written Language. Oxford: Blackwell.

Biber, Douglas, Stig Johansson, Geoffrey Leech, Susan Conrad, and Edward Finegan (1999): Longman Grammar of Spoken and Written English. London: Pearson Education.

Crespo Fernández, Eliecer (2005): "Euphemistic strategies in politeness and face concerns". Pragmalingüística 13: 77-86.

Goffman, E. (1967): Interaction ritual. Garden City. New York: Doubleday.

Gosden, H. (1993): "Discourse functions of subject in scientific research articles". Applied Linguistics 14 (1): 56-57.

Halliday, M. A. K. (1978): “On the language of physical science”. In M. Ghadessey, ed., Registers of Written English. London: Pinter.

Hübler, Axel (1983): Understatements and Hedges in English. Amsterdam: John Benjamins Publishing Company.

Huddleston, Rodney and Geoffrey K. Pullum (2002): The Cambridge Grammar of the English Language. Cambridge: Cambridge University Press.

Hyland, Ken (1998a): Hedging in Scientific Research Articles. Amsterdam: John Benjamins. 
349-382.

. (1998b): "Boosting, hedging and the negotiation of academic knowledge". Text 18 (3):

. (1998c): "Persuasion and context: The pragmatics of academic metadiscourse". Journal of Pragmatics 30: 437-455.

. (2000): Disciplinary Discourses. Social Interactions in Academic Writing. Harlow: Longman Pearson Education.

. (2001): "Humble servants of the discipline? Self mention in research articles". English for Specific Purposes 20: 207-226.

. (2004): “A convincing argument: Corpus analysis and academic persuasion”. In U. Connor,

Ulla and T. A. Upton, eds., Discourse in the Professions: Perspectives from Corpus Linguistics. Amsterdam: Johns Benjamins, 87-112.

Ivanic R. and J. Simpson (1992): “Who's who in academic writing?” In N. Fairclough, ed., Critical Language Awareness. London: Longman, 141-73.

Myers, G. (1989): "The pragmatics of politeness in scientific articles". Applied Linguistics 10: 1-35.

Swales, J. (1990): Genre Analysis: English in Academic and Research Settings. Cambridge: Cambridge University Press.

Ventola, Elija (1995): “What's in an (Academic) Text?”. In B. Warvik, S-K., Tanskanen and R. Hiltunen, eds., Organization in Discourse. Proceedings from the Turku Conference. Anglicana Turkuensia, 109-128.

Winning, Joanne (2000): The Pilgrimage of Dorothy Richardson. Wisconsin: The University of Wisconsin Press. 